\title{
Evaluating Efficiency of Malaysian Banks Using Data Envelopment Analysis
}

\author{
Izah Mohd Tahir (Corresponding author) \\ Faculty of Business Management and Accountancy, University of Darul Iman Malaysia \\ 21300 Kuala Terengganu, Malaysia \\ Tel: 60-9-665-3863 E-mail: izah@udm.edu.my \\ Nor Mazlina Abu Bakar \\ Faculty of Business Management and Accountancy, University of Darul Iman Malaysia \\ 21300 Kuala Terengganu, Malaysia \\ Tel: 60-9-665-3767_E-mail: normazlina@udm.edu.my \\ Sudin Haron \\ President, Kuala Lumpur Business School \\ Suite 4-4-1 Jalan 4/50 Diamond Square Commercial Centre \\ Off Jalan Gombak, 53000 Kuala Lumpur \\ Tel: 60-3-4024-5011Ｅ-mail: sudin@klbs.com.my
}

\begin{abstract}
Data Envelopment Analysis (DEA) Approach is used to estimate the overall, pure technical and scale efficiencies for Malaysian commercial banks during the period 2000-2006. The results suggest that domestic banks were relatively more efficient than foreign banks. Our results also suggest that domestic banks' inefficiency were attributed to pure technical inefficiency rather than scale inefficiency. In contrast, foreign banks inefficiency is attributed to scale inefficiency rather than pure technical inefficiency. The study further examines whether the domestic and foreign banks are drawn from the same environment by performing a series of parametric and non-parametric tests. The results from the parametric and non-parametric tests suggest that for the years 2000-2004, both domestic and foreign banks possessed the same technology whereas results for 2005 and 2006 suggest otherwise. This implies that banks in recent years have had access to different and more efficient technology.
\end{abstract}

Keywords: Efficiency, DEA, Malaysia

\section{Introduction}

The banking system plays an important role in the economic development of any country. Commercial banks, which are the main component of the banking system, have to be efficient otherwise they will create maladjustments and impediments in the process of development in any economy. Technological advancements and globalisation have added to the pressure on the part of the banks to maintain market shares so as to survive and remain competitive. Competition from foreign banks as well from domestic banks themselves creates greater pressure. Commercial banks in Malaysia are of no exception. Therefore not only do commercial banks need to be profitable, but also efficient, since banks are exposed to intense competition both locally and globally. The basic benefit to enhanced efficiency is a reduction in spreads between lending and deposit rates and this will likely stimulate both greater loan demand for industrial investment and greater mobilization of financial savings through the banking system (Ikhide, 2000).

Past studies on bank efficiency and other financial institutions have focussed mainly in the USA (for example Aly et. al., 1990; Elyasiani and Mehdian, 1990; Kwan and Eisenbeis, 1996) and on other developed countries (for example Worthington, 1998 for Australian banking, Koetter, 2005 for German banking). Previous research that has focused on developing countries like Malaysia is still considered small. This motivates us to undertake this study to fill the gap and add to the existing literature. Our study uses unbalanced panel data of 22 banks over the period 2000-2006 and 
employs the non-stochastic approach-Data Envelopment Analysis (DEA) to estimate the technical and scale efficiency of Malaysian commercial banks. We also analyse the sources of inefficiency of these commercial banks, both domestic and foreign banks. The results of this study would be helpful to policy makers as well as scholars and researchers in finance and banking.

The paper is structured as follows: Section 2 will discuss efficiency measurement in banking followed by data and specifications of bank input and outputs in Section 3. Empirical findings are discussed in Section 4 while conclusions are drawn in Section 5.

\section{Efficiency Measurement in Banking}

In the banking literature, two major methods for the empirical estimation on bank efficiency are frequently used: parametric and non-parametric approaches. Parametric methods are considered more sophisticated compared to the non-parametric approach since the method is able to incorporate both input allocative and technical efficiencies. The two main methods frequently used are the Stochastic Frontier Approach (SFA) and the Distribution Free Approach (DFA).

The stochastic frontier approach (SFA), sometimes also referred to as the econometric frontier approach (EFA), was developed by Aigner, Lovell and Schmidt (1977), and Meeusen and Van den Broeck (1977). In this approach, the SFA specifies a functional form for the cost, profit or the production frontier and allows for random error. The SFA modifies a standard cost (production) function to allow inefficiencies to be included in the error term. The predicted standard cost function is assumed to characterize the frontier while any inefficiency is captured in the error term, which is by construction orthogonal to the predicted frontier. These assumption force any measured inefficiencies be uncorrelated with the regressors and any scale or product mix economies derived linearly from these explanatory variables (Ferrier and Lovell, 1990).

Another assumption needed in the SFA is to distinguish the inefficiencies from random components of the error terms. The random components include short term luck which place individual banks in relatively high or low cost positions and measurement error from excluded explanatory variables, misspecification etc. These two components are separated by assuming that inefficiencies are drawn from asymmetric half-normal distribution, and that random errors are drawn from a symmetric normal distribution. However, it is not possible to decompose individuals' residuals into inefficiency or random variation; therefore, estimating technical inefficiency by observation is impossible. Okuda et. al., (2003) used SFA to estimate the cost function of the Malaysian commercial banks from 1991-1997 and its impact on bank restructuring. The study observed economies of scale but not economies of scope and suggested that Malaysian domestic banks were making unproductive capital investments.

In the distribution-free approach (DFA), a functional form for the frontier is also specified but inefficiencies are separated from random error in a different way. Unlike the SFA, the DFA makes no strong assumptions regarding the specific distributions of the inefficiencies or the random errors. The identifying assumption is that efficiency of each bank is stable over time, while random errors tend to average out over time. The estimates of inefficiency for each bank in a panel data set is then determined as the difference between its average residual and the average of the bank on the frontier with some truncated measure performed to account for the failure of the random error to fully average out. The truncation procedure is similar to the TFA treatment of outliers. Therefore, the truncation procedure is used to remove some of the effects of the extreme observations by treating all the most efficient firms alike and, similarly, all the most inefficient firms alike. The DFA has been applied to banking by Berger (1993) in the study of the US banking industry. He found that the frequency distribution of inefficiencies appeared to be closer to the shape of symmetric normal distribution than an asymmetric half-normal distribution. Yildrim and Philippatos (2007) used both SFA and DFA to examine the cost and profit efficiency of banking sectors in twelve countries in Europe and found that the average cost efficiency level was 72 percent by DFA and 77 percent by SFA.

The second approach used in estimating bank efficiency, the non-parametric methods on the other hand, do not presume any explicit functional form for the frontier and construct it from the observed input-output ratios using mathematical programming techniques. The main method frequently used is the Data Envelopment Analysis (DEA).

DEA is rooted in the work of Farell (1957), who used the economic concept of the production frontier and the production possibility set to define technical and allocative efficiencies and later proposed measures of relative inefficiencies. DEA was first introduced by Charnes, Cooper and Rhoades (1978) to describe an application of mathematical programming to observe data to locate the frontier which can then be used to evaluate the efficiency of each of the organizations responsible for the observed output and input quantities.

DEA is based on the concept of efficiency that has been widely used in engineering and the natural sciences to measure the amount of work performed by a machine in relation to the amount of energy consumed in the process. The concept of DEA is similar to that of technical efficiency in the microeconomic theory of production. However, the main difference is that the DEA production frontier is not determined by some specific equation; instead it is generated from 
the actual data for the evaluated firms. Therefore, the DEA efficiency score for a specific firm is defined not by an absolute standard but is relative to the other firms under consideration. This feature differentiates DEA from the parametric approaches discussed earlier, which require a specific functional form. DEA also assumes that all firms face the same unspecified technology, which defines their production possibility set. The main objective of DEA is to determine which firms are operating on their efficient frontier and which firms are not. If the firm's input-output combination lies on the DEA frontier, the firm is considered efficient; and the firm is considered inefficient if the firm's input-output combination lies inside the frontier.

Consider a general situation where we have $\mathrm{n}$ decision making units (DMUs) and each consumes the same $\mathrm{m}$ inputs to produce the same s outputs. Precisely, $\mathrm{DMU}_{\mathrm{j}}$ uses $x_{i j}(I=1,2,3 \ldots, \mathrm{m})$ of input $i$ to produce $y_{r j}(r=1,2 \ldots \ldots, s)$ of output $r$ assuming that $x_{i j}>0$ and $y_{r j}>0$ (Seiford and Thrall, 1990). The specific DMU being evaluated has to solve the following optimization problem:

subject to the constraints:

$$
\operatorname{Maxh}_{0}=\sum_{r=1}^{s} u_{r} y_{r o} / \sum_{i=1}^{m} v_{r} x_{i 0}
$$

$$
\sum_{r=1}^{s} u_{r} y_{r j} / \sum_{i=1}^{m} v_{i} x_{i j} \leq 1, u_{r} \geq 0, v_{i} \geq 0
$$

for $i=1,2, \ldots, m ; r=1,2, \ldots s ; j=1,2, \ldots ., n$. where $\mathrm{h}_{\mathrm{o}}$ is the ratio of virtual outputs to virtual inputs, the $u_{r}$ 's and the $v_{j}$ 's are the variables and the $y_{r o}$ 's and the $x_{j o}$ ' $s$ are the observed output and input values of the DMU to be evaluated. A set of normalizing constraints guarantees that no DMU, including the one evaluated, can obtain an efficiency score that exceeds unity. Thus, DEA establishes a benchmark efficiency score of unity that no individual firm can exceed. If the efficiency score $h_{o}=1, \mathrm{DMU}_{\mathrm{o}}$ satisfies the necessary condition to be DEA efficient; otherwise it is DEA inefficient.

The basic DEA model (CCR model) implied the assumption of constant returns to scale. This assumption was later relaxed to allow for the evaluation of variable returns to scale and scale economies. Specifically, the efficient frontier may be derived using four alternative returns to scale assumptions; constant returns to scale (CR); variable returns to scale (VR), non-increasing returns to scale (NI); and non-decreasing returns to scale (ND). Yue (1992) defined the following assumptions. A bank exhibits increasing returns to scale (IRS) if a proportionate increase in inputs and outputs places it inside the production frontier. A bank exhibits constant returns to scale if a proportionate increase or decrease in inputs or outputs move the firm either along or above the frontier. A bank which is not on the frontier is defined as experiencing non-increasing returns to scale if the hypothetical bank with which it is compared exhibits either constant (CRS) or decreasing returns to scale (DRS). A similar definition applies for non-decreasing returns to scale. A firm which is efficient under the assumption of variables returns to scale (VRS) is considered technologically efficient; the VRS score represents pure technical efficiency (PT), whereas a firm which is efficient under the assumption of constant returns to scale (CRS) is technologically efficient and also uses the most efficient scale of operation. Aly et. al., (1990), suggests that from the measures of technical (T) and pure technical (PT) efficiency, it is possible to derive a measure of scale efficiency:

$$
\begin{aligned}
S=T / P T \text { or } \\
\\
S=C R S / V R S
\end{aligned}
$$

where $0 \leq \mathrm{S} \leq 1$ since $\mathrm{CR} \leq \mathrm{VR}$. If the value of $\mathrm{S}$ equals 1 , the firm is scale efficient and all values less than 1 reflect scale inefficiency. If scale inefficiency exists $(S<1)$, the source of inefficiency is the result of operating at either increasing $(N I<V R)$ or decreasing $(N I=V R)$ returns to scale.

There are a number of studies examining relative efficiency using DEA (Sufian and Abdul Majid 2007; Li 2006; Sufian 2006; Sufian 2004). Sufian and Abdul Majid (2007) analysed efficiency change of Singapore commercial banks during the period of 1993-2003. They found that commercial banks in Singapore exhibited an average overall efficiency of 95.4 percent. Li (2006) investigated the scale-efficiency and technology-efficiency of 14 Chinese commercial banks. She concluded that most banks have low comparative-efficiency. She also found that inefficient banks generally had input surplus. Sufian (2006) investigated the efficiency of non-bank financial institutions in Malaysia for the period 2000-2004. The study found that finance companies were more efficient than merchant banks and that the inefficiency was the result of pure technical inefficiency rather than scale inefficiency. Using DEA to examine the efficiency effects of bank mergers and acquisition in Malaysia, Sufian (2004) found that Malaysian banks exhibited a commendable overall efficiency level of 95.9 percent during 1998-2003 which indicates that the merger programme was successful. 


\section{Data and Specification of Bank Inputs and Outputs}

This study includes all commercial banks where data is available. 9 domestic banks and 13 foreign banks were included (See Table 1). The annual balance sheet and income statement used were taken from BANKSCOPE - Fitch's International Bank Database.

The evaluation of bank efficiency creates several problems which arise as a result of the nature and function of financial intermediaries, especially as banks are multi-product firms that do not produce or market physical products. One of the major problems in the study of bank efficiency is the specification of bank inputs and outputs. There has been long-standing disagreement among researchers over what banks produce. The most debatable issue is the role of deposits and, more specifically, whether they should be treated as inputs and/or outputs. Some researchers such as Elyasiani and Mehdian (1990), and Lang and Welzel (1996), treat them as inputs, but researchers such as Berger and Humphrey (1991), and Ferrier and Lovell (1990), treat deposits as outputs while other researchers such as Humphrey (1990) and Aly et. al., (1990) treat them simultaneously as inputs and outputs.

Generally, there are two ways of measuring bank outputs; the production approach and the intermediation approach. Under the production approach, banks produce accounts of various sizes by processing deposits and loans, and incurring capital and labour costs. Thus, in this approach, outputs are measured by the number of deposits and loan accounts or the number of transactions performed on each type of service provided, and costs are the operating costs needed to produce these products.

Under the intermediation approach, banks are treated as financial intermediaries that combine deposits, labour and capital to produce loans and investments. The values of loans and investments are treated as output measures; labour, deposits and capital are inputs; and operating costs and financial expenses comprise total cost.

The choice of input and output variables thus constitutes a major difficulty, which must be addressed carefully. Such choice however, will be influenced by a number of factors, such as, the selected concept of the banking firm and the questions under consideration. The availability of reliable information also has some effect on the measures used in published research on this topic. Moreover, whether products should be measured in terms of the number of accounts or dollar values depends on the various reasons being considered. For example, Kolari and Zardkoohi (1987), prefer to use dollar values for three reasons: Firstly, banks compete to increase the market share for dollar amounts, as opposed to the number of accounts; secondly, different accounts have different costs; for example, demand deposit accounts might be more costly to maintain than time deposit accounts (although, if these accounts were to have the same costs, then the use of the number of accounts would be equivalent); finally, banks are multi service firms and the dollar amount is the only common denominator; for example, securities investments cannot be measured in terms of number of accounts.

This study uses the intermediation approach to define bank inputs and outputs. Accordingly, two inputs and one output are used consisting of:

Y: Total Earning Assets

$\mathrm{X}_{1}$ : Total Deposits

$\mathrm{X}_{2}$ : Total Overhead Expenses

Table 2 presents the descriptive statistics of outputs and inputs used in the study.

\section{Empirical Findings}

All computation was performed using the DEAFrontier program. The efficiency of commercial banks in Malaysia was first examined by applying the DEA approach for each year by using a separate frontier for domestic and foreign banks. Table 3 reports the mean, standard deviation and extreme values of the various efficiency scores for the groups of banks: domestic and foreign banks for all years 2000-2006. For each year, our results suggest that domestic banks exhibited higher mean overall efficiency ( 88.7 percent) compared to their foreign counterparts ( 73.3 percent). Our results also suggest that domestic bank inefficiency were attributed to pure technical inefficiency rather than scale inefficiency. In contrast, foreign bank inefficiency is attributed to scale inefficiency rather than pure technical inefficiency.

The results for the pooled sample for domestic and foreign banks have in general confirmed our earlier findings that pure technical inefficiency is the dominant factor in influencing domestic bank inefficiency whereas scale inefficiency is the dominant factor in influencing foreign bank inefficiency. During the period 2000-2006, our results suggest that domestic banks exhibited a higher mean pure technical efficiency of 92.4 percent compared to foreign banks (91.5 percent). This suggests that domestic banks are managerially efficient in controlling costs compared to their foreign counterparts. During the period of study, domestic banks exhibited a mean overall efficiency of 88.7 percent, suggesting a mean input waste of 11.3 percent. On the other hand, mean overall efficiency for foreign banks was 73.3 percent, indicating an input waste of 26.7 percent. However, it is interesting to note that the degree of technical efficiency for domestic banks is lower than the degree of scale efficiency, which indicates that a portion of overall inefficiency is due to producing below the production frontier rather than producing on an inefficient scale. 
Figures 1 and 2 depict the mean overall, pure technical efficiency and scale efficiency for commercial banks according to ownership structure for the years 2000 to 2006.

Most of the technical inefficiency exhibited by the banks stem from operating at the wrong scale; ether operating at a scale that was too large (DRS) or operating at a scale that was too small (IRS). Since the major source of inefficiency in the Malaysian commercial bank is scale inefficiency, this study then examines further the trend in the returns to scale of Malaysian commercial banks. The results are reported in Table 4.

The results suggest that the share of scale efficient banks (CRS) was small. The share of scale efficient domestic banks has declined over the six year period; from 29 percent in 2000 to 22 percent in 2006. Similar results are found for foreign banks operating at efficient scale; 27 percent in 2000 declined to 8 percent in 2006.

Overall, the results suggest that a majority of domestic banks are operating in the region of increasing returns to scale. The number of domestic banks experiencing economies of scale (IRS) remained somewhat stable over the period even though the share has increased over the same period (29 percent in 2000 compared to 44 percent in 2006). Similarly, the number of banks experiencing diseconomies of scale (DRS) has remained somewhat stable but the share has declined (43 percent in 2000 compared to 33 percent in 2006). A majority of foreign banks are operating in the region of decreasing returns to scale. The share of foreign banks experiencing economies of scale (IRS) has declined from 27 percent in 2000 to 0 percent in 2006 whereas the share of banks experiencing diseconomies of scale (DRS) has increased from 45 percent in 2000 to 92 percent in 2006.

The results for all years (pooled sample) suggest that the share of domestic banks experiencing economies of scale is 46 percent and the share of domestic banks experiencing diseconomies of scale is 49 percent. A majority of foreign banks are operating at the diseconomies of scale, 93 percent compared to 3 percent operating at economies of scale.

After examining both the efficiency scores and sources of inefficiencies, we investigate further whether each group of bank, domestic and foreign banks, are drawn from the same population and whether these two groups possess the same technology:

$$
\begin{aligned}
& H_{0}=\text { Domestic banks and foreign banks are drawn from the same environment or technology } \\
& H_{l}=\text { Domestic banks and foreign banks are drawn from a different environment or technology }
\end{aligned}
$$

Both parametric (analysis of variance and $t$-test) and non-parametric (Mann-Whithey[Wilcoxon Rank-Sum] and Kolgomorov -Smirnov tests are used to test the null hypothesis that the two groups are drawn from the same population and have identical technologies. The results are presented in Table 5. From the results, we failed to reject the null hypothesis for the first five years (2000-2004) but not for the most recent years (2005 and 2006). This suggests that banks observed in recent years have access to different and more efficient technology compared to those banks in the first five years. Therefore we can conclude that from 2005 onwards, it is appropriate to separate the samples because these two groups of banks, domestic and foreign banks, have different technologies.

\section{Conclusion}

This study attempts to investigate the efficiency of Malaysian commercial banks during the period of 2000-2006. Using A non-parametric approach Data Envelopment Analysis (DEA) methodology enabled us to distinguish between technical, pure technical and scale efficiencies. We have run tests for each year, for domestic banks, foreign banks, and for all banks for all years.

The results suggest that the mean overall or technical efficiency improved during the period under investigation. Overall, for all the years (2000-2006), pure technical efficiency dominates the scale efficiency effects in determining the Malaysian commercial banks overall or technical efficiency. This is confirmed by the overall results (2000-2006), pure technical efficiency is 89.3 percent and scale efficiency is 79.4 percent.

During the period of study, we found that overall or technical efficiency of domestic banks was 73.3 percent, slightly higher than the foreign banks overall or technical efficiency (70.9 percent). The results suggest that domestic banks pure technical efficiency is lower than the degree of scale efficiency implying that during the period of study, domestic banks have been inefficient in controlling their costs rather than operating at the wrong scale. In contrast, foreign bank pure technical efficiency is higher than scale efficiency indicating that foreign banks were operating at the wrong scale of operations rather than producing below the production frontier.

Further investigation indicates that banks observed in recent years have access to different and more efficient technology compared to that in the first five years. Therefore we can conclude that from 2005 onwards, it is appropriate to separate the samples because these two groups of banks, domestic and foreign banks, have access to different technologies and environment. 
As a caveat, the results should be interpreted with caution since previous researches differ substantially regarding different estimation procedures. Further studies should use different estimation approaches allowing a comparison of results.

\section{References}

Aly, H. Y., Grabowski, R., Pasurka, C., \& Rangan, N. (1990). Technical, scale and allocative efficiencies in US banking: An empirical investigation. The Review of Economics and Statistics, 72: 211-218.

Aigner, D. A., Lovell, A.K., \& Schmidt, P. (1977). Formulation and estimation of Stochastic Frontier Production Models. Journal of Econometrics, 6:21-37.

Berger, A. N. (1993). "Distribution-Free" estimates of efficiency in the US banking industry and tests of the Standard Distributional Assumptions. The Journal of Productivity Analysis, 4:261-92.

Berger, A. N. \& Humphrey, D. B. (1991). The Dominance of inefficiencies over scale and product mix economies in banking, Journal of Monetary Economics, 28:117-48.

Charnes, A., Cooper, W.W. \& Rhoades, E. (1978). Measuring the efficiency of Decision Making Units, European Journal of Operational Research, 6:429-444.

Elyasiani, E. \& Mehdian, S. M. (1990). A Nonparametric Approach to measurement of efficiency and technological change: The Case of large U.S. commercial banks. Journal of Financial Services Research, 4 (2): 157-68.

Farell, M. J. (1957). The measurement of productive efficiency. Journal of the Royal Statistical Society 120, Part 111, Series A: 253-81.

Ferrier, G. D., \& Lovell, C. K. (1990). Measuring cost efficiency in banking: econometrics and linear programming evidence. Journal of Econometrics, 46:229-245.

Humphrey, D. B. (1990). Why do estimates of bank scale economies differ? Economic Review, Federal Reserve Bank of Richmond, September/October: 38-50.

Ikhide S. (2000). Efficiency of commercial banks in Namibia. Bank of Nigeria Occasional Paper, No. 4.

Koetter M. (2005). Measurement matters-input price proxies and bank efficiency in Germany, Discussion Paper Series 2: Banking and Financial Studies no. 01.

Kolari, J. \& Zardkoohi A. (1987). Bank Cost, Structure and Performance, Lexington, Mass: Lexington Books.

Kwan S. H., \& Eisenbeis R. A. (1996). An Analysis of Inefficiencies in Banking: A Stochastic Cost Frontier Approach. Federal Reserve Bank of San Francisco Economic Review, No. 2.

Lang, G., \& Welzel, P. (1996). Efficiency and technical progress in banking: Empirical results for a panel of German Cooperative Banks. Journal of Banking and Finance, 20: 1003-23.

Li, Z. (2006). The assessment analysis of efficiency of commercial banks based on DEA Model. International Management Review, 2(3): 60-66.

Meesun, W. \& Broeck, J.V.D. (1977). Efficiency Estimation from Cobb-Douglas Production Functions with Composed Error. International Economic Review, 18(2): 435-44.

Okuda, H., Hashimoto, H. \& Murakami, M. (2003). The estimation of Stochastic Cost Functions of Malaysian commercial banks and its policy implications to bank restructuring. Centre for Economic Institutions Working Paper Series, No. 2003-2.

Sufian, F. (2004). The efficiency effects of bank mergers and acquisitions in a developing economy: Evidence from Malaysia. International Journal of Applied Econometrics and Quantitative Studies, 1-4: 53-74.

Sufian, F. (2006). The efficiency of non-bank financial institutions: Empirical evidence from Malaysia. International Journal of Finance and Economics Issue 6 retrieved from www.eurojournals.com/finance.htm

Sufian, F. \& Abdul Majid, M.Z. (2007). Singapore banking efficiency and its relation to stock returns: A DEA Window Analysis Approach. International Journal of Business Studies, 15(1): 83-106.

Worthington A. C. (1998). The determinants of non-bank financial institution efficiency: A Stochastic Cost Frontier Approach. Applied Financial Economics, 8(3): 279-289.

Yildrim, H. S. \& Philippatos G. C. (2007). Efficiency of banks: Recent evidence from the Transition Economies of Europe, 1993-2000. The European Journal of Finance, 13(2):123-143.

Yue, P. (1992). Data Envelopment Analysis and commercial bank performance: A primer with applications to Missouri banks. Federal Reserve Bank of St. Louis January/February: 31-45. 
Table 1. List of Commercial Banks

\begin{tabular}{ll}
\hline Domestic banks & Foreign Banks \\
\hline Affin Bank Berhad & The Royal Bank of Scotland \\
Alliance Bank Malaysia Berhad & Bangkok Bank Berhad \\
AmBank Malaysia Berhad & Bank of America \\
CIMB Bank Berhad & The Bank of Nova Scotia \\
EON Bank Berhad & Bank of China (Malaysia) Berhad \\
Hong Leong Bank Berhad & Bank of Tokyo-Mitsubishi UFJ (Malaysia) Berhad \\
Malayan Banking Berhad & Citibank Berhad \\
RHB Bank Berhad & HSBC Bank Malaysia Berhad \\
Public Bank Berhad & United Overseas Bank (Malaysia) Bhd. \\
& Standard Chartered Bank Malaysia Berhad \\
& JP Morgan Chase Bank Berhad \\
& OCBC Bank (Malaysia) Berhad \\
& Deutsch Bank \\
\hline
\end{tabular}

Source: Bank Negara Malaysia

Table 2. Descriptive Statistics for Input and Output, 2000-2006 (In RM Million)

\begin{tabular}{clllllll}
\hline \multirow{2}{*}{ All Banks } & Variable & $\mathbf{N}$ & Mean & Median & Minimum & Maximum & Std. Dev. \\
\cline { 2 - 7 }$n$ & & & & & & & \\
$\mathrm{Y}$ & 147 & 28300.14 & 19669.00 & 508.90 & 189518.10 & 34256.54 \\
$\mathrm{X}_{1}$ & 147 & 24477.63 & 17172.50 & 190.10 & 164392.60 & 29819.88 \\
$\mathrm{X}_{2}$ & 147 & 1073.91 & 825.20 & 6.60 & 2784.00 & 1212.98 \\
$\begin{array}{r}\text { Domestic banks } \\
\mathrm{Y}\end{array}$ & 59 & 53196.17 & 38644.60 & 8826.00 & 189518.10 & 40747.25 \\
$\mathrm{X}_{1}$ & 59 & 46037.12 & 33733.30 & 6955.90 & 164392.60 & 35478.75 \\
$\mathrm{X}_{2}$ & 59 & 761.70 & 571.90 & 124.20 & 2784.00 & 572.60 \\
Foreign Banks & & & & & & \\
$\mathrm{Y}$ & 88 & 11608.48 & 3124.30 & 508.90 & 39324.00 & 12660.97 \\
$\mathrm{X}_{1}$ & 88 & 10022.98 & 2614.20 & 190.10 & 35417.30 & 11249.28 \\
$\mathrm{X}_{2}$ & 88 & 191.09 & 63.25 & 6.60 & 875.10 & 231.24 \\
\hline
\end{tabular}


Table 3. Descriptive Statistics of the Efficiency Measures, 2000-2006

\begin{tabular}{|c|c|c|c|c|c|c|c|}
\hline \multicolumn{4}{|c|}{ Domestic Banks } & \multicolumn{4}{|c|}{ Foreign Banks } \\
\hline 2000 & OE & PTE & SE & 2000 & $\mathbf{O E}$ & PTE & SE \\
\hline Mean & 0.949 & 0.970 & 0.978 & Mean & 0.861 & 0.963 & 0.896 \\
\hline Std. Dev & 0.052 & 0.035 & 0.022 & Std. Dev & 0.111 & 0.079 & 0.107 \\
\hline Minimum & 0.869 & 0.915 & 0.936 & Minimum & 0.723 & 0.741 & 0.730 \\
\hline Maximum & 1.000 & 1.000 & 1.000 & Maximum & 1.000 & 1.000 & 1.000 \\
\hline 2001 & OE & PTE & SE & 2001 & OE & PTE & $\mathbf{S E}$ \\
\hline Mean & 0.951 & 0.978 & 0.973 & Mean & 0.889 & 0.975 & 0.913 \\
\hline Std. Dev & 0.035 & 0.035 & 0.025 & Std. Dev & 0.089 & 0.060 & 0.082 \\
\hline Minimum & 0.893 & 0.908 & 0.935 & Minimum & 0.740 & 0.799 & 0.740 \\
\hline Maximum & 1.000 & 1.000 & 1.000 & Maximum & 1.000 & 1.000 & 1.000 \\
\hline 2002 & OE & PTE & SE & 2002 & $\mathbf{O E}$ & PTE & $\mathbf{S E}$ \\
\hline Mean & 0.968 & 0.975 & 0.993 & Mean & 0.792 & 0.939 & 0.845 \\
\hline Std. Dev & 0.036 & 0.035 & 0.005 & Std. Dev & 0.138 & 0.084 & 0.133 \\
\hline Minimum & 0.889 & 0.898 & 0.985 & Minimum & 0.609 & 0.762 & 0.609 \\
\hline Maximum & 1.000 & 1.000 & 1.000 & Maximum & 1.000 & 1.000 & 1.000 \\
\hline 2003 & $\mathbf{O E}$ & PTE & SE & 2003 & $\mathbf{O E}$ & PTE & SE \\
\hline Mean & 0.905 & 0.973 & 0.930 & Mean & 0.858 & 0.955 & 0.896 \\
\hline Std. Dev & 0.065 & 0.037 & 0.047 & Std. Dev & 0.134 & 0.071 & 0.106 \\
\hline Minimum & 0.833 & 0.913 & 0.869 & Minimum & 0.654 & 0.776 & 0.720 \\
\hline Maximum & 1.000 & 1.000 & 1.000 & Maximum & 1.000 & 1.000 & 1.000 \\
\hline 2004 & OE & PTE & SE & 2004 & $\mathbf{O E}$ & PTE & SE \\
\hline Mean & 0.945 & 0.984 & 0.961 & Mean & 0.855 & 0.958 & 0.891 \\
\hline Std. Dev & 0.053 & 0.025 & 0.044 & Std. Dev & 0.125 & 0.063 & 0.104 \\
\hline Minimum & 0.852 & 0.939 & 0.869 & Minimum & 0.680 & 0.802 & 0.728 \\
\hline Maximum & 1.000 & 1.000 & 1.000 & Maximum & 1.000 & 1.000 & 1.000 \\
\hline 2005 & OE & PTE & SE & 2005 & $\mathbf{O E}$ & PTE & SE \\
\hline Mean & 0.946 & 0.981 & 0.964 & Mean & 0.845 & 0.976 & 0.865 \\
\hline Std. Dev & 0.043 & 0.034 & 0.032 & Std. Dev & 0.137 & 0.049 & 0.124 \\
\hline Minimum & 0.886 & 0.895 & 0.919 & Minimum & 0.633 & 0.856 & 0.641 \\
\hline Maximum & 1.000 & 1.000 & 1.000 & Maximum & 1.000 & 1.000 & 1.000 \\
\hline 2006 & OE & PTE & SE & 2006 & $\mathbf{O E}$ & PTE & $\mathbf{S E}$ \\
\hline Mean & 0.935 & 0.987 & 0.947 & Mean & 0.845 & 0.989 & 0.854 \\
\hline Std. Dev & 0.045 & 0.021 & 0.042 & Std. Dev & 0.101 & 0.023 & 0.098 \\
\hline
\end{tabular}




\begin{tabular}{lccc|lcrrr}
\cline { 5 - 8 } Minimum & 0.886 & 0.940 & 0.886 & Minimum & 0.741 & 0.928 & 0.741 \\
Maximum & 1.000 & 1.000 & 1.000 & Maximum & 1.000 & 1.000 & 1.000 \\
\hline All & OE & PTE & SE & All & OE & PTE & SE \\
\hline Mean & 0.887 & 0.924 & 0.961 & Mean & 0.733 & 0.915 & 0.803 \\
Std. Dev & 0.049 & 0.054 & 0.036 & Std. Dev & 0.126 & 0.073 & 0.132 \\
Minimum & 0.788 & 0.807 & 0.862 & Minimum & 0.516 & 0.732 & 0.574 \\
Maximum & 1.000 & 1.000 & 1.000 & Maximum & 1.000 & 1.000 & 1.000
\end{tabular}

Note: $\mathrm{OE}=$ Overall efficiency, $\mathrm{PTE}=$ Pure technical efficiency, $\mathrm{SE}=$ Scale efficiency

Table 4. Developments in Returns to Scale (RTS) in Malaysian Commercial Banks According to Ownership

\begin{tabular}{clcccc}
\hline Year & Ownership & IRS & CRS & DRS & Total \\
\hline \multirow{2}{2}{000} & Domestic Banks & $2(29)$ & $2(29)$ & $3(43)$ & $7(100)$ \\
& Foreign Banks & $3(27)$ & $3(27)$ & $5(45)$ & $11(100)$ \\
\hline \multirow{2}{*}{2001} & Domestic Banks & $4(50)$ & $2(25)$ & $2(25)$ & $8(100)$ \\
& Foreign Banks & $4(36)$ & $3(27)$ & $5(45)$ & $11(100)$ \\
\hline \multirow{2}{*}{2002} & Domestic Banks & $3(38)$ & $2(25)$ & $3(38)$ & $8(100)$ \\
& Foreign Banks & $1(8)$ & $2(15)$ & $10(77)$ & $13(100)$ \\
\hline \multirow{2}{*}{2004} & Domestic Banks & $3(33)$ & $2(22)$ & $4(44)$ & $9(100)$ \\
& Foreign Banks & $0(0)$ & $4(31)$ & $9(69)$ & $13(100)$ \\
\hline \multirow{2}{*}{2005} & Domestic Banks & $4(44)$ & $2(22)$ & $3(33)$ & $9(100)$ \\
& Foreign Banks & $2(15)$ & $3(23)$ & $8(62)$ & $13(100)$ \\
\hline \multirow{2}{*}{2006} & Domestic Banks & $4(44)$ & $2(22)$ & $3(33)$ & $9(100)$ \\
& Foreign Banks & $1(8)$ & $3(23)$ & $9(69)$ & $13(100)$ \\
\hline \multirow{2}{*}{$(2000-2006)$} & Domestic Banks & $4(44)$ & $2(22)$ & $3(33)$ & $9(100)$ \\
& Foreign Banks & $0(0)$ & $1(8)$ & $12(92)$ & $13(100)$ \\
\hline & Domestic Banks & $27(46)$ & $3(5)$ & $29(49)$ & $59(100)$ \\
& Foreign Banks & $3(3)$ & $3(3)$ & $82(93)$ & $88(100)$ \\
\hline
\end{tabular}

Note: Figures in parentheses are in percentages 
Table 5. Summary of Parametric and Non-Parametric Tests

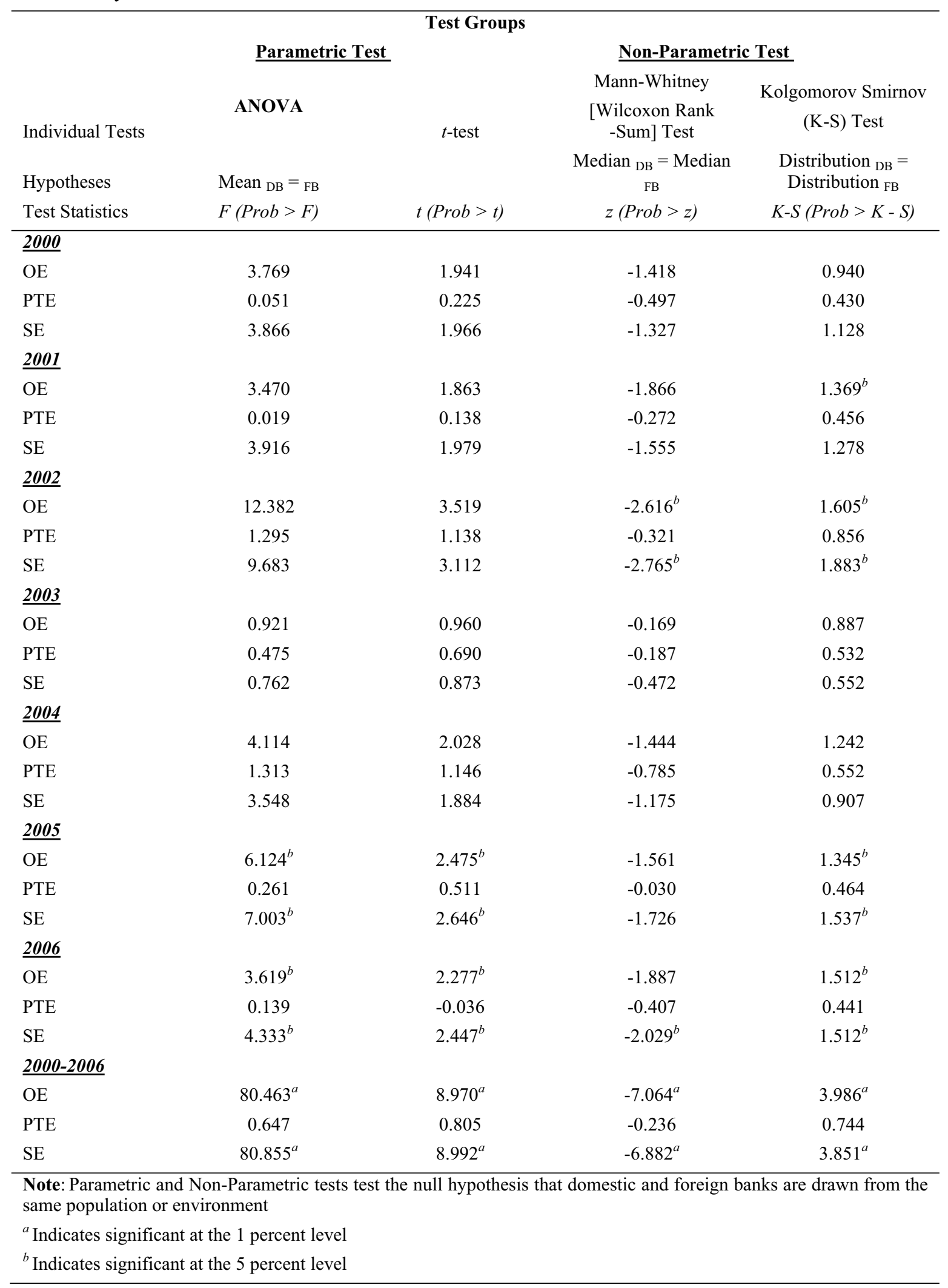



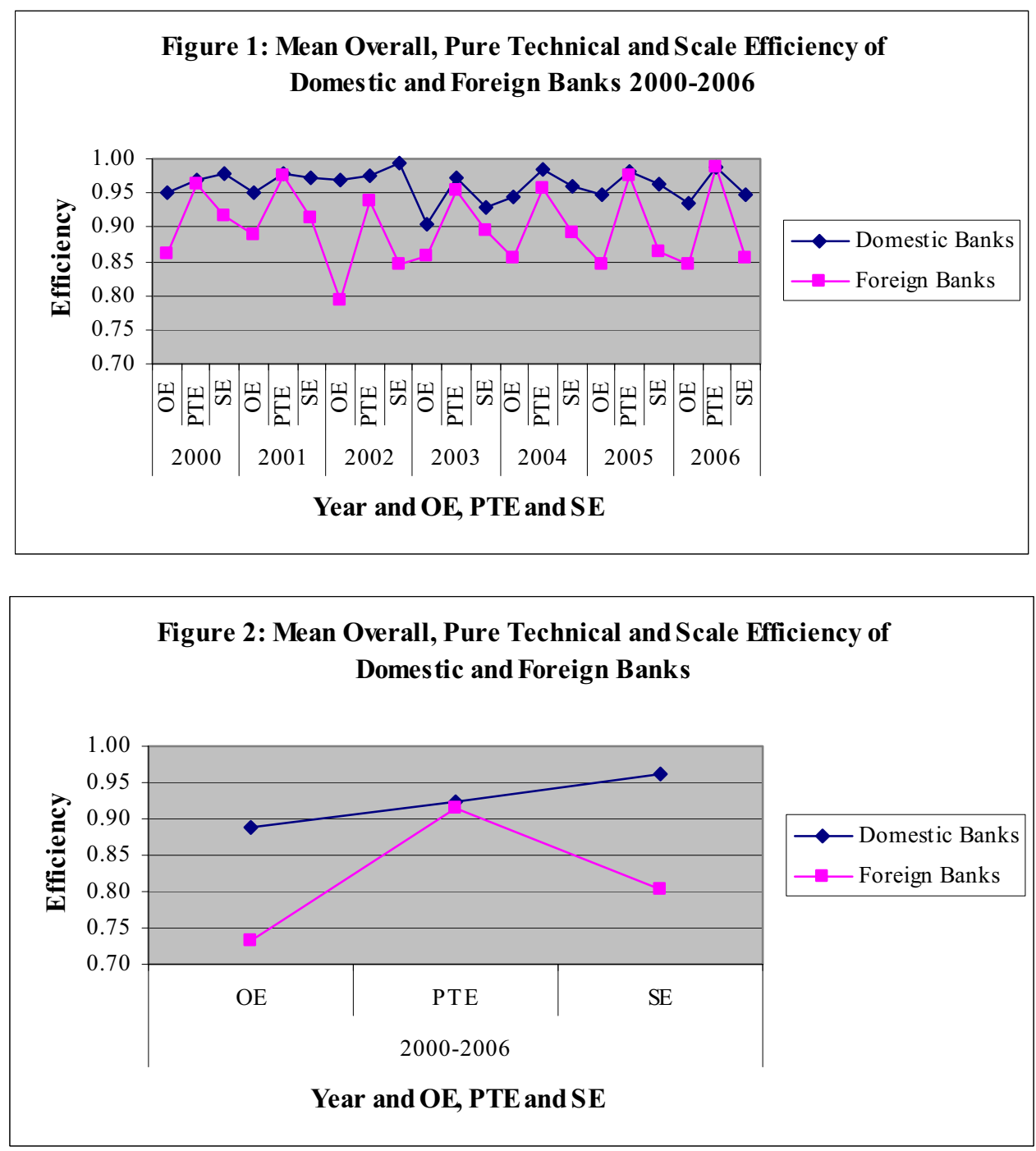